\title{
HUBUNGAN CITRA DIRI DENGAN PERILAKU NARSISISME PADA REMAJA PUTRI PENGGUNA INSTAGRAM DI KOTA PRABUMULIH
}

\author{
Ayu Purnamasari'), Veby Agustin ${ }^{2)}$ \\ Program Studi Psikologi Fakultas Kedokteran Universitas Sriwijaya, Palembang \\ 1)ayupurnamasari@ fk.unsri.ac.id, ${ }^{2)}$ agustinveby@gmail.com
}

\begin{abstract}
The purpose of research was to know the relationship between self-image and narcissism behavior of female teenagersas instagram usersat Prabumulih city. The hypothesis was there's a relationship between self-image and narcissism behavior of female teenagersas instagram usersat Prabumulih city.The population was female teenagersin Prabumulih city aged 18-24 years old as instagram active users. 151 person used for research sample, 50 person used for try out, were taken using incidental sampling. The variabels was measured by the scale of narcissism behavior from Raskin and Hall and self-image from Wagner. Data analysis used correlation Pearson Product Moment. Analysis of correlation Pearson Product Moment obtained by value of $r=0.772, p=0.000$ ( $p<0.05)$. It proved that hypothesis is accepted. There's significant positive correlation between self-image and narcissism behavior. It means that higher self-image makes higher narcissism behavior of female teenagers as instagram usersat Prabumulih city.
\end{abstract}

Keyword: Self-image, narcissism behavior

\begin{abstract}
ABSTRAK: Tujuan penelitian adalah untuk menguji hubungan citra diri dengan perilaku narsisisme pada remaja putri pengguna instagram di Kota Prabumulih. Dilatarbelakangi oleh sebuah survey yang dilakukan oleh The Royal Society for Public Health yang menyimpulkan bahwa instagram tergolong media sosial yang berdampak buruk untuk kesehatan jiwa. Dengan demikian instagram menjadi fenomena sosial yang patut di cermati, remaja menjadi semakin gemar show off atau menampilkan dirinya kepada khalayak dengan kebebasan yang diberikan oleh instagram. Mereka menjadi lebih merasa percaya diri untuk mengunggah dan membagikan foto ataupun video, sehingga menyebabkan munculnya sikap narsisisme berkembang di instagram. Hipotesis penelitian yaitu terdapat hubungan antara citra diri dengan perilaku narsisisme remaja putri pengguna instagram di Kota Prabumulih. Populasi dalam penelitian ini adalah remaja putri di Kota Prabumulih berusia 18-24 tahun sebagai pengguna aktif instagram. Sampel penelitian sebanyak 151 remaja putri, diambil menggunakan teknik sampling insidental. Alat ukur menggunakan skala perilaku narsisisme dari Raskin dan Hall (1979) dan citra diri dari Wagner (Seamands, 1981). Analisis data menggunakan teknik korelasi Pearson Product Moment, dengan hasil diperoleh nilai $r=0,772, p=0,000(p<0,05)$. Hal ini menunjukan hipotesis yang diajukan diterima. Artinya semakin tinggi citra diri yang dimiliki, maka semakin tinggi perilaku narsisisme remaja putri di Kota Prabumulih sebagai pengguna aktif instagram.
\end{abstract}

Kata Kunci: Citra diri, perilaku narsisisme

\section{PENDAHULUAN}

Istilah narsisisme sering kali didengar dalam keilmuan psikologi, dan sudah mulai biasa digunakan dalam percakapan sehari-hari dikalangan kaum muda. Namun makna dari hal ini sendiri masih kurang dipahami oleh masyarakat.

Narsisisme dalam keilmuan psikologi sering dikaitkan dengan suatu gangguan kepribadian. Meskipun demikian dalam perkembangannya narsisisme tidak selalu merupakan gangguan kepribadian, seperti yang dikemukakan oleh Emmons et al (Bergman et al, 2011) secara subklinis narsisisme adalah sifat kepribadian yang normal dan banyak penelitian menunjukkan validitas narsisisme sebagai ciri kepribadian yang normal. Kemudian menurut Campbell dan Miller (2011) narsisisme biasanya dikonseptualisasikan oleh peneliti kepribadian sosial sebagai variabel perbedaan individu yang stabil yang dapat diukur secara reliabel dalam sampel normal (nonklinis).

Penyebab seseorang berprilaku narsisisme dapat diakibatkan oleh beberapa hal, seperti hasil dari penelitian Santi 
(2017) bahwa perilaku narsisisme seseorang dapat diukur berdasarkan tingkat harga diri. semakin rendah harga diri seseorang, maka semakin tinggi narsisnya, sebaliknya semakin tinggi harga diri seseorang maka semakin rendah perilaku narsisisme orang tersebut. Selain harga diri, kontrol diri juga memiliki hubungan dengan narsisisme. Hasil penelitian dari Handayani (2014) menunjukan bahwa terdapat hubungan negatif yang sangat signifikan antara kontrol diri dengan narsisisme.

Di zaman modern ini perkembangan teknologi semakin pesat, begitu juga dengan internet. Awalnya internet digunakan sebagai media untuk komunikasi jarak jauh. Namun saat ini dapat digunakan dalam berbagai hal seperti media informasi, hiburan, media jual beli, dan media sosial.

Media sosial merupakan sarana komunikasi masa kini yang berkembang pesat dari berbagai macam klasifikasi dan tipe sesuai dengan kebutuhan masyarakat dunia (Manampiring, 2015). Dengan perkembangannya media sosial menjadi sangat akrab dalam kehidupan, dan penggunanya hampir dari setiap kalangan terutama remaja, karena masa remaja merupakan masa dimana seseorang memulai pergaulan sosialnya secara lebih luas (Devya, 2015). Melalui media sosial remaja dapat memulai pergaulan sosialnya tidak hanya dengan orang-orang yang biasa ditemui dalam lingkungan keseharian mereka, tetapi juga dengan orang-orang baru.

Terdapat berbagai jenis media sosial yang sangat populer saat ini, dan dari berbagai jenis media sosial tersebut yang paling banyak diminati oleh anak muda dengan rentang usia 18-24 tahun (remaja) adalah instagram, dengan mayoritas pengguna di Indonesia berjenis kelamin perempuan. Hal ini berdasarkan hasil survey penelitian yang dilakukan oleh research market dunia, TNS (Taylor Nelson Sofres), atas 506 pengguna instagram di indonesia (Vania, 2016).

Survey bertajuk Status of Mind yang dilakukan oleh The Royal Society for Public Health menyimpulkan bahwa instagram tergolong media sosial yang berdampak buruk untuk kesehatan jiwa (Widiartanto, 2017). Dengan demikian instagram menjadi fenomena sosial yang patut dicermati, karena banyak masyarakat yang tertarik menjadi pengguna, terutama kalangan remaja. Remaja menjadi semakin gemar show off atau menampilkan dirinya kepada khalayak dengan kebebasan yang diberikan oleh instagram. Mereka menjadi lebih merasa percaya diri untuk mengunggah dan membagikan foto ataupun video, sehingga menyebabkan munculnya sikap narsisisme berkembang di instagram.

Kota Prabumulih berkembang dengan pesatnya penggunaan teknologi dan pengetahuan (Jayanto, 2009). Pemerintah kota meluncurkan program smartcity untuk mendukung program pembangunan pemerintah demi mengenalkan internet kepada masyarakat di daerah dan kota terpencil. Pemerintah melengkapi taman kota dengan fasilitas jaringan internet atau wifi gratis, dengan tujuan agar taman kota semakin ramai dikunjungi masyarakat terkhusunya para pelajar maupun mahasiswa yang membutuhkan akses internet.

Berdasarkan hasil observasi peneliti, dengan perkembangan dan fasilitas teknologi yang terus berkembang, remaja di Kota Prabumulih juga menunjukan perkembangan dalam mengakses dan menggunakan fasiltas internet tersebut. Terlihat dari hampir semua remaja di Kota Prabumulih terkhususnya remaja putri aktif menggunakan media sosial instagram.

Perilaku remaja menjadikan kebanyakan fitur-fitur media sosial salah satunya instagram digunakan hanya untuk memperlihatkan siapa dirinya serta kondisi terbarunya yang kemudian dibagikan secara bebas kepada pengguna lainnya. Setiap foto-foto atau video yang di-publish oleh para pengguna instagram merupakan foto atau video terpilih yang akan menunjukan kondisi terbaik dari dirinya, yang sering kali tidak sesuai dan jauh berbeda dengan kondisi sesungguhnya. Sehingga menampilkan hidup yang mereka miliki seolah-olah positif dan ideal, dengan tujuan mendapatkan pujian dan tidak dilecehkan 
oleh orang lain serta untuk menumpang popularitas agar dianggap tidak ketinggalan zaman oleh teman-temannya.

Berdasarkan hasil survey awal yang dilakukan pada tanggal 10-13 September 2017 terhadap 35 remaja putri di Kota Prabumulih dengan rentang usia 18-24 tahun, diketahui bahwa $100 \%$ responden merupakan pengguna aktif dengan intensitas menggunakan instagram setiap harinya. Sebesar $25,7 \%$ pengguna berusia 21-22 tahun dengan 65,7\% kegiatan yang paling sering dilakukan oleh mereka saat menggunakan instagram adalah memposting foto serta video dengan mayoritas alasan responden sebesr 20\% untuk memperoleh pujian dari temantemannya dan salah satu alasan lainnya yaitu $14,3 \%$ merasa bangga jika foto dan videonya dilihat oleh teman-teman yang lain. Hal ini menunjukan adanya perilaku narsisisme pada remaja putri pengguna instagram di Kota Prabumulih.

Hal inilah yang terjadi dikalangan remaja zaman sekarang terkhususnya remaja putri. Hubungan sosial melalui media sosial instagram dijadikan sebagai sarana untuk mencapai popularitas dan eksistensi. Banyak remaja yang berlombalomba memperbanyak postingan foto atau videonya untuk memperoleh like dan followers agar memperoleh rasa percaya diri dan bangga, sehingga bisa dianggap sebagai seseorang yang eksis didunia maya.

Fenomena ini didukung dengan hasil wawancara singkat yang dilakukan peneliti dengan 2 orang remaja SMA di Kota Prabumulih yang berusia 18 tahun serta aktif menggunakan instagram. Mereka menyebutkan bahwa dengan ikut aktif menggunakan instagram dapat membuat diri mereka menjadi lebih terkenal. Dengan memposting foto-foto mereka ke instagram, orang-orang dapat mengetahui kegiatan yang mereka lakukan, orang juga dapat melihat style atau gaya mereka, bisa menambah likers atau followers di instagram sehingga bisa menjadi eksis di media sosial instagram. Kemudian berdasarkan hasil survey awal pada 35 remaja putri di Kota Prabumulih sebanyak $54,3 \%$ keinginan untuk menjadi eksis didunia maya merupakan alasan utama responden menjadi pengguna aktif instagram, dan dengan hasil $71,4 \%$ saat mendapatkan like dan followers mereka merasa menjadi orang yang eksis di media sosial instagram.

Keinginan untuk menjadi eksis ini identik dengan orang yang memiliki kepribadian narsisisme. Menurut Pincus et al (2009) narsisisme dapat dikonseptualisasikan sebagai kemampuan seseorang untuk mempertahankan citra diri yang relatif positif melalui berbagai proses pemahaman diri dan pengaturan diri. Hal ini berarti narsisisme berhubungan dengan citra diri seseorang yang terlampau positif, yang memandang bahwa dirinya sangat baik, optimis dan positif terhadap dirinya sendiri.

Citra diri adalah keseluruhan sistem gambar dan perasaan seseorang mengenai dirinya sendiri (Seamands, 1981). Bagi remaja putri fisik sangatlah penting, kebanyakan mereka mementingkan citra diri secara fisik untuk menarik perhatian lawan jenis termasuk bersosialisasi dengan teman sebaya. Remaja akan cenderung mengubah dirinya agar telihat berbeda dari orang lain, salah satu cara yang dilakukan dengan memperhatikan penampilan fisiknya (Suhartanti, 2016).

Hal inilah yang dilakukan para remaja zaman sekarang melalui media sosial instagram, mereka memposting gambar, foto dan video dirinya yang paling menarik untuk memamerkan kelebihan yang ada pada diri, seperti tampilan fisik dan style. Tidak jarang foto dan video tersebut sudah dimanipulasi, foto dan video yang di-posting ke instagram sudah melalui serangkaian proses editing agar tampilan fisik mereka terlihat sesuai dengan keinginan atau telihat jauh lebih baik dan pada akhirnya menampilkan hal yang jauh berbeda dengan kondisi yang sesungguhnya. Keinginan menonjolkan diri sendiri, asik menghibur diri sendiri melalui gadget, akan mengarahkan individu menjadi lebih individualis, kepekaan sosial terhadap lingkungan menjadi berkurang karena sibuk narsis di media sosial.

Berdasarkan hasil survey awal 
$100 \%$ responden memandang bahwa diri mereka menarik dan 94,3\% responden memandang bahwa dirinya merupakan orang yang cerdas, dengan demikian dapat dilihat bahwa sebagian besar responden memandang dan mengidentifiksi dirinya berdasarkan apa yang dilihat atau diyakini oleh dirinya sendiri. Selanjutnya sebesar 97,1\% responden mem-posting foto-foto dan video menarik yang mereka miliki ke instagram, beberapa dari mereka menyebutkan bahwa hanya foto-foto dan video pilihan yang menunjukan kondisi terbaik dan menarik dari diri mereka yang akan di posting ke instagram. Kemudian $45,7 \%$ responden mengaku melakukan proses editing terlebih dahulu sebelum memposting foto-fotonya ke instagram dengan tujuan dirinya dapat terlihat jauh lebih menarik dan cantik.

Individu narsisisme memiliki citra diri positif yang terlampau tinggi. Pernyataan ini diperkuat oleh pernyataan Campbell dan Miller (2011) bahwa secara interpersonal, individu narsis sangat kreatif dalam mencoba mengelola kesan yang mereka sampaikan kepada orang lain sehingga bisa mengejar citra diri mereka yang diinginkan

Berdasarkan penjelasan dan fenomena diatas peneliti tertarik untuk meneliti Apakah ada hubungan citra diri dengan perilaku narsisisme pada remaja putri pengguna instagram di Kota Prabumulih?

\section{Narsisisme}

Model narsisisme pertama yang muncul dalam psikologi dikemukakan oleh Freud (Campbell dan Miller, 2011) yang percaya bahwa narsisisme adalah hasil dari individu yang melampirkan sebagian besar energi psikis mereka kepada diri sendiri dan relatif sedikit terhadap orang lain. Freud menyatakan bahwa proses tersebut akan mengarahkan individu narsis mengembangkan tingkat penghormatan yang benar-benar tinggi untuk diri mereka sendiri. Kemudian Santrock (2002) menyebutkan bahwa narsisisme merupakan pendekatan terhadap orang lain yang berpusat pada diri sendiri.
Menurut American Psychiatric Assosiation (VandenBos, 2007) narsisisme adalah cinta diri yang berlebihan atau keterpakuan pada diri sendiri. Seiring dengan pendapat tersebut Chaplin (2005) mengatakan bahwa narsisisme adalah cintadiri, perhatian yang sangat berlebihan kepada diri sendiri. Sedangkan menurut pendapat Reich (Campbell dan Miller, 2011) narsisisme adalah bentuk regulasi harga diri yang patologis dimana inflasi dan agresi diri digunakan untuk melindungi konsep diri seseorang.

Berdasarkan beberapa pendapat ahli yang telah peneliti paparkan, dapat peneliti simpulkan bahwa narsisisme merupakan bentuk dari keinginan individu untuk mempertunjukan bahwa dirinya merupakan orang yang sempurna, pandai dan penting dibanding orang lainnya agar memperoleh perhatian dan pemujaan atas dirinya.

\section{Faktor-faktor penyebab narsisisme}

Lubis (Apsari, 2012) menyebutkan beberapa faktor penyebab narsisisme yaitu faktor biologis, psikoanalisa, dan sosiokultural seperti yang akan diuraikan sebagai berikut:

a. Faktor psikologis.

Narsisisme terjadi karena tingkat aspirasi yang tidak realistis atau berkurangnya penerimaan terhadap diri sendiri.

b. Faktor biologis.

Secara biologis gangguan narsisisme lebih banyak dialami oleh individu yang orangtuanya penderita neurotik. Selain itu jenis kelamin, usia, fungsi hormonal dan struktur-struktur fisik yang lain ternyataberhubungan dengan narsisisme.

c. Faktor sosiologis.

Narsisisme dialami oleh semua orang dengan berbagai lapisan dan golongan terhadap perbedaan yang nyata antara kelompok budaya tertentu dan reaksi narsisisme yang dialaminya. 


\section{Komponen narsisisme}

Raskin and Hall (1979) membagi komponen narsisisme menjadi tujuh yaitu:

a. Authority

Individu narsisisme memiliki kemampuan dan prestasi yang cenderung tidak realistis. Merasa dirinya penting atau unik dan beranggapan sebagai pemimpin. Misalnya, seorang siswa mengekspresikan pandangan bahwa dia lebih daripada murid lainnya.

b. Self-sufficiency

Individu narsisisme sibuk dengan fantasi dalam kemampuan, kekuatan, kekayaan, kecemerlangan, kecantikan, atau cinta ideal.

c. Superiority

Individu narsisisme percaya bahwa mereka lebih unggul atau spesial. Harga diri mereka seringkali rapuh; sibuk dengan seberapa baik yang dia lakukan dan seberapa baik dia dipandang oleh orang lain. Menanggapi kritik, kekalahan, atau kekecewaan, sebagai bentuk ketidak pedulian atau sebagai rasa marah, inferioritas, malu, penghinaan, atau kekosongan.

d. Exhibitionism

Individu narsisisme terus mencari kekaguman dan perhatian, dan lebih perduli dengan penampilan daripada yang lainnya. Misalnya, lebih berfokus agar terlihat dengan orang yang "tepat" dari pada keinginan memiliki teman dekat.

e. Exploitativeness

Memanfaatkan orang lain untuk memenuhin hasrat sendiri atau untuk menguatkan diri sendiri dan integritas pribadi serta hak orang lain diabaikan. Misalnya, seorang penulis berteman dengan tujuan untuk menjiplak gagasan orang lain.

f. Vanity

Keyakinan yang berlebihan terhadap kemampuan atau daya tarik terhadap orang lain.

g. Entitlement

Individu narsisisme mengharapkan perlakuan khusus tanpa adanya hubungan timbal balik. Misalnya, kejutan dan kemarahan dirasakan karena orang lain tidak melakukan apa yang diinginkan; lebih banyak pengharapan terhadap orang lain dari pada hal-hal yang realistis.

\section{Karakteristik narsisisme}

Campbell dan Miller (2011)

berpendapat bahwa seseorang narsisisme memiliki beberapa karakteristik yang membuat pola perhatian dan penilaian mereka berfokus pada diri sendiri :

a. Memiliki fokus perhatian yang berlebihan pada diri sendiri.

b. Cenderung mengarahkan percakapan kepada diri sendiri dan tidak mau mendengarkan orang lain.

c. Sering menggunakan kata ganti orang pertama.

\section{Jenis-jenis narsisisme}

Kohut \& Wolf (Levy, 2012) menggambarkan tiga jenis narsisisme berdasarkan hubungan interpersonal:

a. The merger-hungry, individu yang harus terus-menerus melampirkan dan mendefinisikan diri mereka melalui orang lain;

b. The contact-shunning, individu yang menghindari kontak sosial karena takut perilaku mereka tidak akan dikagumi atau diterima; dan

c. The mirror-hungry, individu yang cenderung menampilkan diri di depan orang lain.

\section{Level (tingkatan) narsisisme}

Campbell dan Miller (2011) menggambarkan tingkatan narsisisme sebagai berikut :

a. Narsisisme yang sehat dicirikan oleh diri yang terintegrasi yang mencerminkan kesadaran dan penerimaan kekuatan dan kelemahan seseorang. Narsisisme yang sehat memungkinkan untuk memuaskan hubungan dengan orang lain dan memungkinkan kepuasan dalam hal pekerjaan, ambisi, dan ekspresi kreatif, untuk kemampuan memenuhi kebutuhan dan keinginan seseorang 
tanpa kebingungan dan kegelisahan yang tidak semestinya, dan kapasitas untuk hidup dalam harmoni yang setara dengan prinsip dan nilai moral orang lain.

b. Narsisisme pada tingkat neurotik ditandai oleh pengaturan psikologis di mana ada rasa diri yang terintegrasi secara umum. Individu-individu ini menunjukkan kebutuhan yang berlebihan untuk kekaguman dari orang lain, sikap berkepentingan dan eksploitasi terhadap orang lain, kurang berempati, dan iri yang berlebihan. Individu dengan patologi ini menunjukkan adaptasi superfi yang baik, namun pengalaman subyektif mereka berada antara delusi dan elation.

c. Narsisisme pada borderlinelevel mencakup individu yang menunjukkan manifestasi khas dari gangguan kepribadian narsisistik. Selain itu, pasien ini hadir dengan kurangnya toleransi terhadap kecemasan, kurangnya kontrol impuls, pengurangan fungsi subliminatif yang parah, yang ditunjukkan pada kegagalan (parah) di bidang kerja, kegagalan dalam upaya membangun atau mempertahankan hubungan intim (cinta), dan reaksi kemarahan berlebih sebagai bentuk kebesaran (grandiose) self.

d. Narsisisme maligant adalah bentuk yang lebih patologis yang ditandai dengan agresi egosyntonik, paranoid intens, dan sifat antisosial. Bagi orangorang seperti itu, kebesaran (grandiose) diri tidak hanya terpengaruh oleh agresi, tapi juga bertahan melalui identifikasi dengan hukuman, primitif, dan kuat, yang memberi ilusi kemenangan atas rasa sakit, kematian, dan keterbatasan melalui serangan tanpa henti terhadap diri sendiri dan orang lain

\section{Citra Diri}

Menurut American Psychiatric Assosiation (VandenBos, 2007) self-image atau citra diri merupakan pandangan atau konsep diri seseorang, berupa aspek penting dari kepribadian seseorang yang dapat menentukan keberhasilan hubungan dan general well-being seseorang.

Sedangkan Gunawan (2003) mengemukakan bahwa citra diri adalah cara individu melihat dirinya sendiri dan menentukan prestasi dimasa sekarang. Seiring dengan pernyataan tersebut Hoft (2001) mengatakan bahwa citra diri adalah cara seseorang memandang diri sendiri, bukan hanya ketika menatap kedalam cermin dan memandang penampilan luar, melainkan apa yang mereka percayai tentang diri sendiri. Hal ini senada dengan dengan pendapat Burns (1993) yang mengatakan bahwa citra diri adalah apa yang dilihat seseorang ketika dia melihat pada dirinya sendiri.

Chaplin (2005) berpendapat bahwa citra diri (self-image) adalah jati diri seperti yang digambarkan atau yang dibayangkan akan menjadi dikemudian hari. Gambaran diri ini bisa sangat berbeda dengan diri sendiri yang sebenarnya. Kemudian menurut Seamands (1981) citra diri adalah keseluruhan sistem gambar dan perasaan seseorang mengenai dirinya sendiri.

Berbeda dengan pendapat yang dikemukakan oleh tokoh lainnya yang mendefiniskan citra diri berhubungan dengan gambaran atau pandangan terhadap diri sendiri, Matthew (1997) berpendapat bahwa citra diri adalah cetak biru yang dengan tepat menentukan perilaku seseorang, orang-orang yang bergaul dengan mereka, apa yang mereka usahakan dan yang akan mereka hindari.

Dari uraian di atas dapat disimpulkan oleh peneliti bahwa citra diri adalah gambaran serta pandangan dan keyakinan individu secara keseluruhan mengenai dirinya sendiri.

\section{Faktor-faktor pembentuk citra diri}

Faktor-faktor pembentuk citra diri bersumber dari luar diri seseorang yaitu pengalaman pribadi dan hasil internalisasi dari penilaian orang lain. Jika seseorang hidup dilingkungan negatif maka akan terbentuk citra diri yang negatif begitupun sebaliknya (Lusi, 2010). Penyataan tersebut 
senada dengan pernyataan yang dikemukakan oleh Holden (2007) bahwa citra diri terbentuk dari penilaian yang dibuat oleh diri sendiri maupun oleh orang lain dan citra diri terbentuk dari informasi, pengalaman, umpan balik dan kesimpulan yang dibuat diri sendiri.

\section{Komponen citra diri}

Beynon (2008) menjelaskan bahwa terdapat beberapa kompenen citra diri yang diuraikan sebagai berikut:

a. Performance of Roles

Komponen ini menjelaskan tentang kemampuan dan seberapa baik seseorang dalam berbagai hal, seberapa sukses seseorang pada apa yang ia lakukan. Seperti dalam hal pendidikan, olahraga, karier, kehidupan rumah, atau pola asuh atau peran lainnya yang sangat spesifik.

b. Pedigree

Komponen ini menjelaskan tentang identitas seseorang dan merupakan sumber rasa kebanggaan yang dimiliki seseorang. Dapat berupa latar belakang, asal, warisan keluarga atau status seseorang, sekolah atau universitas tempat menempuh pendidikan.

c. Acceptability to Others

Komponen ini merupakan penerimaan individu kepada orang lain, perasaan terhadap hubungan dengan teman, pasangan atau orangtua, juga sebagai wilayah di mana latar belakang individu dapat memiliki efek yang sangat nyata pada masa kini pengalaman seseorang untuk dicintai di masa lalu sering beralih ke bagaimana seseorang melihat dirinya sendiri atau mengevaluasi kasih sayang orang lain pada saat ini.

d. Significance

Komponen ini menjelaskan tentang arti hidup, bagaimana seseorang menganggap pentingnya ia didunia: di mana seseorang meyesuaikan diri dengan skema besar didalam hidup, bagaimana dirinya akan diingat, atau dampak yang akan dibuat.

\section{Karakteristik citra diri}

Lusi (2010) mengatakan bahwa setiap orang memiliki citra diri yang berbeda. Ada yang memiliki citra diri negatif ada yang memiliki citra diri postif dan ada pula yang berada pada tingkatan campuran antara negatif dan positif. Hal ini berkaitan dengan keadaan tertentu yang dialami. Citra diri negatif adalah gambaran dari individu yang salah mengenal diri dan salah mendefinisikan dirinya sedangkan citra diri positif adalah tahap ideal tertentu yang dibangun atas dasar yang tepat. Berikut karakteristik dari citra diri tersebut:

a. Citra diri negatif

1) Salah kenal diri.

2) Salah perlakuan diri.

3) Salah jalani diri.

4) Hidup dalam diri bayangan.

b. Citra diri antara postif dan negatif

1) Kenal diri sejati secara kognitif.

2) Tidak maksimal perlakukan diri.

3) Tidak maksimal jalani diri.

4) Kadang-kadang terjebak dalam diri bayangan.

c. Citra diri positif

1) Kenal diri.

2) Perlakukan diri dengan benar.

3) Jalani diri dengan benar.

4) Hidup dengan diri sejati.

\section{Pengaruh citra diri}

Holden (2007) menyebutkan:

a. Citra diri sangat mempengaruhi cara berkomunikasi dengan orang lain. Pada dasarnya hubungan dengan orang lain merupakan perpanjangan dari hubungan dengan diri sendiri. Penerimaan diri yang buruk bisa menjadi penyebab tingkat kemandirian yang tidak sehat, kompetisi, rasa iri, pengekangan diri, terlalu berusaha menyenangkan hati orang lain dan penyiksaan diri. Sedangkan penerimaan diri yang positif bisa membantu mengembangkan keakraban, keramahan dan kesuksesan secara keseluruhan. 
b. Bagaimana anda memandang diri sendiri menentukan jenis peran yang diambil dalam hubungan dengan orang lain, di tempat kerja dan di dalam hidup secara umum. Citra diri merupakan penasihat internal yang membing seseorang untuk melakukan atau tidak melakukan sesuatu.

\section{METODE PENELITIAN}

Penelitian ini menggunakan pendekatan kuantitatif dengan populasi seluruh remaja putri di Kota Prabumulih yang aktif menggunakan instagram, namun jumlah remaja putri diKota Prabumulih yang aktif sebagai pengguna instagram tidak diketahui

\section{Karakteristik responden penelitian}

Karakteristik responden dalam penelitian ini, yaitu:

1. Berjenis Kelamin Wanita

2. Usia dengan rentang 18-24 tahun.

3. Remaja di Kota Prabumulih yang aktif menggunakan instagram.

Berdasarkan hasil observasi peneliti, subjek dapat dikatakan sebagai pengguna aktif adalah pengguna yang membuka instagram dan meng-upload foto/video dalam satu minggu terakhir atau setidaknya meng-update instastory dalam satu minggu terakhir.

\section{Teknik pengambilan sampel}

Pemilihan subjek menggunakan teknik nonprobality sampling yang tidak memberi peluang/kesempatan sama bagi setiap unsur atau anggota populasi untuk dipilih menjadi sampel.Teknik sampling yang digunakan adalah sampling insidental. Jumlah sampel yang diambil dalam penelitian ini berdasarkan teori Roscoe, bahwa ukuran sample yang layak dalam penelitian antara 30-500. Oleh karena itu, jumlah sampel dalam penelitian ini sebanyak 151 orang dengan jumlah sampel untuk uji coba (try out) sebanyak 50 orang.

\section{Metode pengumpulan data}

Dalam penelitian ini, peneliti menggunakan beberapa metode pengumpulan data antara lain:

1. Skala model skala Likert

a. Skala Perilaku Narsisisme

Peneliti memodifikasi skala baku untuk mengukur perilaku narsisisme remaja putri pengguna instagram di Kota Prabumulih yaitu Narcissim Personality Inventory (NPI-40) dari Raskin dan Hall (1979). Peneliti memodifikasi jawaban pada penelitian ini dari dua pilihan menjadi empat pilihan jawaban dan menyesuaikan kalimat aitem dengan fenomena yang hendak diukur. Narcissistic Personality Inventory (NPI-40) disusun berdasarkan tujuh komponen kepribadian narsisisme yaitu Authority, Self-Sufficiency, Superiority, Exhibitionism, Exploitativeness, Vanity, and Entitlement (Raskin dan Hall, 1979). Validitas dan reabilitas skala telah teruji, dengan skor internal reliability $(\alpha=0,72)$ dan $(r=0,90)$. Jumlah aitem untuk NPI-40 berjumlah 40kisi-kisi aitem yang terdiri dari 20 aitem favorable dan 20 item unfavorable.

b. Skala Citra Diri

Skala ini mengungkap tingkat citra diri remaja putri pengguna instagram diKota Prabumulih. Skala ini disusun berdasarkan komponen citra diri menurut Wagner (Seamands, 1981:67) yaitu Sense of Belongingness; of Being Loved, Sense of Worth and Value, dan Sense of Being Competence.

2. Wawancara dan observasi dilakukan pada saat hendak memastikan fenomena, survey latar belakang, pada saat dan setelah pengambilan data.

\section{Uji hipotesis}

penelitian ini mengajukan hipotesis assosiatif menggunakan teknik analisis korelasi Pearson Product Moment. 


\section{HASIL DAN PEMBAHASAN}

\section{Deskripsi subjek penelitian}

Subjek dalam penelitian ini berjumlah 151 orang yang merupakan remaja putri Kota Prabumulih dengan batasan usia remaja menurut Sarwono (2016: 3).

Tabel 1. Deskripsi usia subjek penelitian

\begin{tabular}{ccc}
\hline Usia & Jumlah & Persentase \\
\hline 18th & 16 & $10,6 \%$ \\
19th & 27 & $17,9 \%$ \\
20th & 30 & $19,9 \%$ \\
21th & 36 & $23,8 \%$ \\
22th & 27 & $17,9 \%$ \\
23th & 13 & $8,6 \%$ \\
24th & 2 & $1,3 \%$ \\
\hline Total & $\mathbf{1 5 1}$ & $\mathbf{1 0 0 \%}$ \\
\hline
\end{tabular}

Berdasarkan data di atas, dapat dilihat bahwa subjek dengan rentang usia 20-22 tahun sebagai subyek terbanyak.

Adapun sebaran subjek berdasarkan status pendidikan dapat dilihat dalam tabel 2.

Tabel 2. Deskripsi status pendidikan subjek penelitian

\begin{tabular}{lcc}
\hline Pekerjaan & Jumlah & Persentase \\
\hline Siswi & 10 & $6,6 \%$ \\
Mahasiswi & 141 & $93,4 \%$ \\
\hline \multicolumn{1}{c}{ Total } & $\mathbf{1 5 1}$ & $\mathbf{1 0 0 \%}$ \\
\hline
\end{tabular}

Ditinjau dari status sebagian besar subjek merupakan mahasiswi yang berjumlah 141 orang dengan persentase sebesar 93,4\%.

Kemudian untuk sebaran subjek berdasarkan jumlah followers instagram dapat dilihat pada tabel 3 .

Tabel 3. Deskripsi jumlah followers Instagram subjek penelitian

\begin{tabular}{ccc}
\hline $\begin{array}{c}\text { Jumlah } \\
\text { Followers }\end{array}$ & Jumlah & Persentase \\
\hline $200-500$ & 21 & $13,9 \%$ \\
$500-800$ & 48 & $31,8 \%$ \\
$800-1100$ & 38 & $25,2 \%$ \\
$1100-1400$ & 20 & $13,2 \%$ \\
$1400-1700$ & 4 & $2,6 \%$
\end{tabular}

\begin{tabular}{ccc}
$1700-2000$ & 5 & $3,3 \%$ \\
$>2000$ & 15 & $9,9 \%$ \\
\hline Total & $\mathbf{1 5 1}$ & $\mathbf{1 0 0 \%}$ \\
\hline
\end{tabular}

Berdasarkan data diatas, dapat diketahui bahwa subjek penelitian dengan jumlah followers sebanyak 500-800 memiliki jumlah terbanyak yaitu 48 orang dengan persentase sebesar 31,8\%.

Selanjutnya yaitu sebaran subjek berdasarkan waktu subjek menggunakan instagram terkahir kalinya dapat dilihat dalam tabel 4.

Tabel 4. Deskripsi waktu subjek terakhir kali menggunakan Instagram

\begin{tabular}{lcc}
\hline $\begin{array}{l}\text { Waktu Terakhir } \\
\begin{array}{l}\text { Menggunakan } \\
\text { Instagram }\end{array}\end{array}$ & Jumlah & $\begin{array}{c}\text { Persen- } \\
\text { tase }\end{array}$ \\
\hline <1 Jam yang lalu & 105 & $69,5 \%$ \\
1-2 Jam yang lalu & 12 & $7,9 \%$ \\
2-3 Jam yang lalu & 7 & $4,6 \%$ \\
3-4 Jam yang lalu & 3 & $2 \%$ \\
4-5 Jam yang lalu & 2 & $1,3 \%$ \\
5-6 Jam yang lalu & 2 & $1,3 \%$ \\
> 6 Jam yang lalu & 20 & $13,2 \%$ \\
\hline \multicolumn{1}{c}{ Total } & $\mathbf{1 5 1}$ & $\mathbf{1 0 0 \%}$ \\
\hline
\end{tabular}

Berdasarkan data keseluruhan subjek diatas, dapat disimpulkan bahwa sebagian besar subjek merupakan pengguna instagram yang aktif, dapat dilihat bahwa subjek yang terakhir kali menggunakan instagramnya $<1$ jam yang lalu berjumlah 105 orang dengan persentase sebesar $69,5 \%$.

Setelah melakukan analisis deskriptif, peneliti kemudian menggolongkan frekuensi subjek berdasarkan skor yang diperoleh kedalam kategori-kategori menjadi rendah, sedang dan tinggi.

Tabel 5. Kategorisasi perilaku narsisisme pada subjek penelitian

\begin{tabular}{llrc}
\hline Skor & Kategori & f & \% \\
\hline $\mathrm{X}<52$ & Rendah & 0 & $0 \%$ \\
$52 \leq \mathrm{X}<78$ & Sedang & 108 & $71,5 \%$ \\
$\mathrm{X} \geq 78$ & Tinggi & 43 & $28,5 \%$ \\
\hline \multicolumn{2}{c}{ Total } & $\mathbf{1 5 1}$ & $\mathbf{1 0 0 \%}$ \\
\hline
\end{tabular}

Berdasarkan deskripsi kategorisasi 
diatas, dapat dilihat bahwa sebagian besar subjek penelitian memiliki tingkatan perilaku narsisime dalam kategori sedang yaitu berjumlah 108 orang dengan persentase sebesar $71,5 \%$.

Adapun kategorisasi perilaku narsisisme pada subjek penelitian berdasarkan jumlah followers instagram yang dimiliki oleh subjek penelitian sebagai berikut :

Tabel 6. Kategorisasi perilaku narsisisme berdasarkan jumlah followers Instagram

\begin{tabular}{|c|c|c|c|c|}
\hline \multirow{2}{*}{$\begin{array}{l}\text { Jumlah } \\
\text { Followers }\end{array}$} & \multicolumn{3}{|c|}{ Kategorisasi } & \multirow[b]{2}{*}{$\mathbf{N}$} \\
\hline & $\begin{array}{l}\text { Ren- } \\
\text { dah }\end{array}$ & $\begin{array}{c}\text { Se- } \\
\text { dang }\end{array}$ & $\begin{array}{c}\text { Ting- } \\
\text { gi }\end{array}$ & \\
\hline $200-500$ & 0 & 21 & 0 & 21 \\
\hline $500-800$ & 0 & 47 & 1 & 48 \\
\hline $800-1100$ & 0 & 29 & 9 & 38 \\
\hline $1100-1400$ & 0 & 10 & 10 & 20 \\
\hline $1400-1700$ & 0 & 0 & 4 & 4 \\
\hline $1700-2000$ & 0 & 1 & 4 & 5 \\
\hline$>2000$ & 0 & 0 & 15 & 15 \\
\hline Total & 0 & 108 & 43 & $\begin{array}{c}15 \\
1\end{array}$ \\
\hline
\end{tabular}

Berdasarkan data diatas, subjek penelitian yang memiliki perilaku narsisisme yang tinggi dengan jumlah yang paling banyak merupakan subjek yang mempunyai jumlah followers instagram $1100-1400$ yaitu sebanyak 10 orang (50\%).

Tabel 7. Kategorisasi citra diri pada subjek penelitian

\begin{tabular}{|c|c|c|c|}
\hline Skor & Kategori & f & $\%$ \\
\hline$X<38$ & Negatif & 0 & $0 \%$ \\
\hline $38 \leq X<57$ & $\begin{array}{c}\text { Antara } \\
\text { positif \& } \\
\text { negatif }\end{array}$ & 104 & $68,9 \%$ \\
\hline$X \geq 57$ & Positif & 47 & $31,1 \%$ \\
\hline \multicolumn{2}{|c|}{ Total } & 151 & $100 \%$ \\
\hline
\end{tabular}

Berdasarkan deskripsi kategorisasi diatas, dapat dilihat bahwa tidak terdapat subjek penelitian yang memiliki citra diri yang negatif, sebagian besar subjek penelitian memiliki citra diri pada kategori diantara positif dan negatif yaitu berjumlah 104 orang dengan persentase sebesar $68,9 \%$.

\section{Uji Hipotesis}

Tabel 8. Distribusi hasil uji hipotesis penelitian

\begin{tabular}{cccc}
\hline \multirow{2}{*}{ Variabel } & \multicolumn{2}{c}{$\begin{array}{c}\text { Pearson } \\
\text { Correlation }\end{array}$} & \multirow{2}{*}{ Ket } \\
\cline { 2 - 3 } & $\mathbf{R}$ & Sig. & \\
\hline $\begin{array}{c}\text { Perilaku } \\
\text { Narsisisme } \\
\text { - Citra Diri }\end{array}$ & 0,772 & 0,000 & Signifikan \\
\hline
\end{tabular}

Berdasarkan hasil uji hipotesis diatas, diperoleh nilai signifikansi sebesar $0,000(\mathrm{p}<0,01)$ dan nilai koefisien korelasi (r) antara variabel perilaku narsisisme dengan citra diri sebesar 0,772. Hal tersebut menunjukan bahwa hipotesis pada penelitian ini diterima yaitu terdapat hubungan antara perilaku narsisisme dengan citra diri.

Peneliti melakukan uji beda ( $u j i$ one way anova) terhadap masing-masing variabel. Deskripsi data tersebut adalah sebagai berikut:

Tabel 9. Distribusi hasil uji beda berdasarkan usia subjek penelitian

\begin{tabular}{ccc}
\hline Variabel & F & Sig. \\
\hline Perilaku Narsisisme & 1,309 & 0,257 \\
Citra Diri & 1,161 & 0,330 \\
\hline
\end{tabular}

Dari tabel diatas dapat diketahui bahwa tidak terdapat perbedaan tingkat perilaku narsisisme dan citra diri jika dilihat dari usia subjek penelitian.

Peneliti melakukan uji beda (uji $t$ test) terhadap masing-masing variabel. Deskripsi data tersebut adalah sebagai berikut:

Tabel 10. Distribusi hasil uji beda berdasarkan status pendidikan subjek penelitian

\begin{tabular}{ccc}
\hline Variabel & $\begin{array}{c}\text { Levene's } \\
\text { test }\end{array}$ & Sig. \\
\hline Perilaku Narsisisme & 0,723 & 0,869 \\
Citra Diri & 0,258 & 0,509 \\
\hline
\end{tabular}

Dari tabel diatas dapat diketahui bahwa tidak terdapat perbedaan tingkat 
perilaku narsisisme dan citra diri berdasarkan status pendidikan subjek penelitian.

Tabel 11. Distribusi hasil uji beda berdasarkan jumlah followers Instagram subjek penelitian

\begin{tabular}{cccc}
\hline Variabel & F & Sig. & Ket. \\
\hline Perilaku & 28,510 & 0,000 & $\begin{array}{c}\text { Ada } \\
\text { Perbedaan } \\
\text { Narsisisme }\end{array}$ \\
$\begin{array}{c}\text { Ada } \\
\text { Citra Diri }\end{array}$ & 22,513 & 0,000 & \begin{tabular}{c} 
Perbedaan \\
\hline
\end{tabular} \\
\hline
\end{tabular}

Dari tabel diatas dapat diketahui bahwa terdapat perbedaan tingkat perilaku narsisisme dan citra diri berdasarkan jumlah followers instagram subjek penelitian.

Tabel 12. Signifikansi perbedaan perilaku narsisisme berdasarkan jumlah followers Instagram

\begin{tabular}{|c|c|c|c|}
\hline $\begin{array}{c}\text { Jumlah } \\
\text { Followers }\end{array}$ & $\begin{array}{c}\text { Jumlah } \\
\text { Followers }\end{array}$ & Sig. & Ket. \\
\hline \multirow{6}{*}{$200-500$} & $500-800$ & 0,000 & $\begin{array}{c}\text { Ada } \\
\text { Perbedaan }\end{array}$ \\
\hline & $800-1100$ & 0,000 & $\begin{array}{c}\text { Ada } \\
\text { Perbedaan }\end{array}$ \\
\hline & $\begin{array}{c}1100- \\
1400\end{array}$ & 0,000 & $\begin{array}{c}\text { Ada } \\
\text { Perbedaan }\end{array}$ \\
\hline & $\begin{array}{l}1400- \\
1700\end{array}$ & 0,000 & $\begin{array}{c}\text { Ada } \\
\text { Perbedaan }\end{array}$ \\
\hline & $\begin{array}{l}1700- \\
2000\end{array}$ & 0,000 & $\begin{array}{c}\text { Ada } \\
\text { Perbedaan }\end{array}$ \\
\hline & $>2000$ & 0,000 & $\begin{array}{c}\text { Ada } \\
\text { Perbedaan }\end{array}$ \\
\hline \multirow{5}{*}{$500-800$} & $800-1100$ & 0,003 & $\begin{array}{c}\text { Ada } \\
\text { Perbedaan }\end{array}$ \\
\hline & $\begin{array}{l}1100- \\
1400\end{array}$ & 0,000 & $\begin{array}{c}\text { Ada } \\
\text { Perbedaan }\end{array}$ \\
\hline & $\begin{array}{l}1400- \\
1700\end{array}$ & 0,001 & $\begin{array}{c}\text { Ada } \\
\text { Perbedaan }\end{array}$ \\
\hline & $\begin{array}{l}1700- \\
2000\end{array}$ & 0,001 & $\begin{array}{c}\text { Ada } \\
\text { Perbedaan }\end{array}$ \\
\hline & $>2000$ & 0,000 & $\begin{array}{c}\text { Ada } \\
\text { Perbedaan } \\
\end{array}$ \\
\hline \multirow{4}{*}{$800-1100$} & $\begin{array}{l}1100- \\
1400\end{array}$ & 1,000 & $\begin{array}{l}\text { Tidak Ada } \\
\text { Perbedaan }\end{array}$ \\
\hline & $\begin{array}{l}1400- \\
1700\end{array}$ & 0,175 & $\begin{array}{c}\text { Ada } \\
\text { Perbedaan }\end{array}$ \\
\hline & $\begin{array}{l}1700- \\
2000\end{array}$ & 0,299 & $\begin{array}{c}\text { Ada } \\
\text { Perbedaan }\end{array}$ \\
\hline & $>2000$ & 0,000 & $\begin{array}{c}\text { Ada } \\
\text { Perbedaan }\end{array}$ \\
\hline
\end{tabular}

\begin{tabular}{|c|c|c|c|}
\hline \multirow{4}{*}{$\begin{array}{l}1100- \\
1400\end{array}$} & $1400-$ & 1,000 & Tidak Ada \\
\hline & $\begin{array}{l}1700 \\
1700-\end{array}$ & 1000 & Tidak Ada \\
\hline & 2000 & 1,000 & Perbedaan \\
\hline & $>2000$ & 0,034 & $\begin{array}{c}\text { Ada } \\
\text { Perbedaan }\end{array}$ \\
\hline \multirow{2}{*}{$\begin{array}{c}1400- \\
1700\end{array}$} & 1700- & 1,000 & Tidak Ada \\
\hline & $>2000$ & 1,000 & $\begin{array}{l}\text { Tidak Ada } \\
\text { Perbedaan }\end{array}$ \\
\hline $\begin{array}{l}1700- \\
2000\end{array}$ & $>2000$ & 1,000 & $\begin{array}{l}\text { Tidak Ada } \\
\text { Perbedaan }\end{array}$ \\
\hline
\end{tabular}

Dengan demikian kerena terdapat perbedaan pada variabel perilaku narsisisme, peneliti melakukan analisis lanjutan untuk melihat perbedaan rata-rata pada variable perilaku narsisisme. Berikut deskripsi perbedaan rata-rata tersebut seperti pada tabel 13.

Tabel 13 Perbedaan rata-rata perilaku narsisisme berdasarkan jumlah followers Instagram

\begin{tabular}{lll}
\hline $\begin{array}{l}\text { Jumlah } \\
\text { Followers }\end{array}$ & $\begin{array}{l}\text { Rata-rata } \\
\text { (mean) }\end{array}$ & $\begin{array}{l}\text { Jumlah } \\
\text { Subjek }\end{array}$ \\
\hline $200-500$ & 61,67 & 21 \\
$500-800$ & 68,79 & 48 \\
$800-1100$ & 73,47 & 38 \\
$1100-1400$ & 75,80 & 20 \\
$1400-1700$ & 81,25 & 4 \\
$1700-2000$ & 80,00 & 5 \\
$>2000$ & 81,87 & 15 \\
\hline
\end{tabular}

Berdasarkan data diatas dapat disimpulkan bahwa semakin banyak jumlah followers instagram yang dimiliki subjek penelitian semakin meningkat jumlah ratarata perilaku narsisisme pada subjek.Terbukti subjek yang memiliki jumlah followers instagram >2000 memiliki rata-rata tingkatan perilaku narsisisme paling tinggi yaitu sebesar 81,87 .

Selanjutnya peneliti juga menyajikan tabel lebih jelas mengenai perbedaan citra diri subjek penelitian berdasarkan jumlah followers instagram: 
Tabel 14. Signifikansi perbedaan citra diri berdasarkan jumlah followers Instagram

\begin{tabular}{|c|c|c|c|}
\hline $\begin{array}{c}\text { Jumlah } \\
\text { Followers }\end{array}$ & $\begin{array}{c}\text { Jumlah } \\
\text { Followers }\end{array}$ & Sig. & Ket. \\
\hline \multirow{6}{*}{$200-500$} & $500-800$ & 0,000 & $\begin{array}{c}\text { Ada } \\
\text { Perbedaan }\end{array}$ \\
\hline & $800-1100$ & 0,000 & $\begin{array}{c}\text { Ada } \\
\text { Perbedaan }\end{array}$ \\
\hline & $1100-1400$ & 0,000 & $\begin{array}{c}\text { Ada } \\
\text { Perbedaan }\end{array}$ \\
\hline & $1400-1700$ & 0,000 & $\begin{array}{c}\text { Ada } \\
\text { Perbedaan }\end{array}$ \\
\hline & $1700-2000$ & 0,000 & $\begin{array}{c}\text { Ada } \\
\text { Perbedaan }\end{array}$ \\
\hline & $>2000$ & 0,000 & $\begin{array}{c}\text { Ada } \\
\text { Perbedaan }\end{array}$ \\
\hline \multirow{5}{*}{$500-800$} & 800-1100 & 1,000 & $\begin{array}{l}\text { TidakAda } \\
\text { Perbedaan }\end{array}$ \\
\hline & $1100-1400$ & 0,000 & $\begin{array}{c}\text { Ada } \\
\text { Perbedaan }\end{array}$ \\
\hline & $1400-1700$ & 0,014 & $\begin{array}{c}\text { Ada } \\
\text { Perbedaan }\end{array}$ \\
\hline & $1700-2000$ & 0,000 & $\begin{array}{c}\text { Ada } \\
\text { Perbedaan }\end{array}$ \\
\hline & $>2000$ & 0,000 & $\begin{array}{c}\text { Ada } \\
\text { Perbedaan }\end{array}$ \\
\hline \multirow{4}{*}{$800-1100$} & $1100-1400$ & 0,041 & $\begin{array}{c}\text { Ada } \\
\text { Perbedaan }\end{array}$ \\
\hline & $1400-1700$ & 0,118 & $\begin{array}{l}\text { Tidak Ada } \\
\text { Perbedaan }\end{array}$ \\
\hline & $1700-2000$ & 0,005 & $\begin{array}{c}\text { Ada } \\
\text { Perbedaan }\end{array}$ \\
\hline & $>2000$ & 0,000 & $\begin{array}{c}\text { Ada } \\
\text { Perbedaan }\end{array}$ \\
\hline \multirow{3}{*}{$1100-1400$} & $1400-1700$ & 1,000 & $\begin{array}{l}\text { Tidak Ada } \\
\text { Perbedaan }\end{array}$ \\
\hline & $1700-2000$ & 1,000 & $\begin{array}{l}\text { Tidak Ada } \\
\text { Perbedaan }\end{array}$ \\
\hline & $>2000$ & 0,142 & $\begin{array}{l}\text { Tidak Ada } \\
\text { Perbedaan }\end{array}$ \\
\hline \multirow[t]{2}{*}{$1400-1700$} & $1700-2000$ & 1,000 & $\begin{array}{l}\text { Tidak Ada } \\
\text { Perbedaan }\end{array}$ \\
\hline & $>2000$ & 1,000 & $\begin{array}{l}\text { Tidak Ada } \\
\text { Perbedaan }\end{array}$ \\
\hline $1700-2000$ & $>2000$ & 1,000 & $\begin{array}{l}\text { Tidak Ada } \\
\text { Perbedaan }\end{array}$ \\
\hline
\end{tabular}

Berdasarkan data diatas, dapat diketahui bahwa terdapat perbedaan citra diri pada sebagian besar subjek penelitian berdasarkan jumlah followers instagram dengan signifikansi $0,000-0,041 \quad(p<0,05)$. Namun tidak terdapat perbedaan citra diri antara subjek yang memiliki jumlah followers 1400-1700 dengan 800-1100, 1100-1400, 1700-2000, dan >2000 dengan 1700-2000.

Dengan demikian kerena terdapat perbedaan pada variabel citra diri, peneliti melakukan analisis lanjutan untuk melihat perbedaan rata-rata pada variable citra diri. Berikut deskripsi perbedaan rata-rata tersebut.

Tabel 15. Perbedaan rata-rata citra diri berdasarkan jumlah followers Instagram

\begin{tabular}{lll}
\hline $\begin{array}{l}\text { Jumlah } \\
\text { Followers }\end{array}$ & $\begin{array}{l}\text { Rata-rata } \\
\text { (mean) }\end{array}$ & $\begin{array}{l}\text { Jumlah } \\
\text { Subjek }\end{array}$ \\
\hline $200-500$ & 46,86 & 21 \\
$500-800$ & 51,52 & 48 \\
$800-1100$ & 52,92 & 38 \\
$1100-1400$ & 56,65 & 20 \\
$1400-1700$ & 59.25 & 4 \\
$1700-2000$ & 60,60 & 5 \\
$>2000$ & 60,67 & 15 \\
\hline
\end{tabular}

Berdasarkan data diatas dapat disimpulkan bahwa semakin banyak jumlah followers instagram yang dimiliki subjek penelitian semakin tinggi rata-rata citra diri pada subjek penelitian.Terbukti subjek yang memiliki jumlah followers instagram $>2000$ memiliki rata-rata citra diri paling tinggi dibandingkan subjek yang lainnya yaitu sebesar 60,67.

Untuk mengetahui ada atau tidaknya perbedaan rata-rata tingkat narsisisme dan citra diri pada subjek penelitian berdasarkan waktu terakhir kali menggunakan instagram, peneliti melakukan uji beda (uji one way anova) terhadap masing-masing variabel. Deskripsi data tersebut adalah sebagai berikut :

Tabel 16. Distribusi hasil uji beda berdasarkan waktu terakhir kali menggunakan Instagram

\begin{tabular}{|c|c|c|c|}
\hline Variabel & $\mathbf{F}$ & Sig. & Ket. \\
\hline $\begin{array}{l}\text { Perilaku } \\
\text { Narsisisme }\end{array}$ & 5,638 & 0,000 & $\begin{array}{c}\text { Ada } \\
\text { Perbedaan }\end{array}$ \\
\hline Citra Diri & 4,541 & 0,000 & $\begin{array}{c}\text { Ada } \\
\text { Perbedaan }\end{array}$ \\
\hline
\end{tabular}

Dari tabel diatas dapat diketahui bahwa terdapat perbedaan tingkat perilaku narsisisme dan citra diri berdasarkan waktu terakhir kali subjek menggunakan instagram.

Berikut ini peneliti menyajikan tabel lebih jelas mengenai perbedaan perilaku narsisisme berdasarkan waktu 
terakhir kali subjek penelitian menggunakan instagram.

Tabel 17. Signifikansi perbedaan perilaku narsisisme berdasarkan waktu terakhir Kali menggunakan Instagram

\begin{tabular}{cccc}
\hline $\begin{array}{c}\text { Waktu } \\
\text { Terakhir } \\
\begin{array}{c}\text { Menggunakan } \\
\text { Instagram }\end{array}\end{array}$ & $\begin{array}{c}\text { Jumlah } \\
\text { Followers }\end{array}$ & Sig. & Ket. \\
\hline & $\begin{array}{c}\text { 1-2 Jam } \\
\text { yang lalu }\end{array}$ & 1,000 & $\begin{array}{c}\text { Tidak Ada } \\
\text { Perbedaan }\end{array}$ \\
\cline { 2 - 4 } & $\begin{array}{c}\text { 2-3 Jam } \\
\text { yang lalu }\end{array}$ & 0,146 & $\begin{array}{c}\text { Tidak Ada } \\
\text { Perbedaan }\end{array}$ \\
\cline { 2 - 4 } & $\begin{array}{c}\text { 3-4 Jam } \\
\text { yang lalu }\end{array}$ & 0,127 & $\begin{array}{c}\text { Tidak Ada } \\
\text { Perbedaan }\end{array}$ \\
\cline { 2 - 4 } <1 Jam & $\begin{array}{c}\text { 4-5 Jam } \\
\text { yang lalu }\end{array}$ & 0,498 & $\begin{array}{c}\text { Tidak Ada } \\
\text { Perbedaan }\end{array}$ \\
\cline { 2 - 4 } yang lalu & $\begin{array}{c}\text { 5-6 Jam } \\
\text { yang lalu }\end{array}$ & 0,795 & $\begin{array}{c}\text { Tidak Ada } \\
\text { Perbedaan }\end{array}$ \\
\cline { 2 - 4 } & $\begin{array}{c}\text { 6 Jam } \\
\text { yang lalu }\end{array}$ & 0,004 & $\begin{array}{c}\text { Ada } \\
\text { Perbedaan }\end{array}$ \\
\hline
\end{tabular}

Berdasarkan data diatas, dapat diketahui bahwa terdapat perbedaan perilaku narsisisme dengan signifikansi $0,004(\mathrm{p}<0,05)$ antara subjek penelitian yang terakhir kali menggunakan instagram $<1$ jam yang lalu dengan subjek yang terakhir kali menggunakan instagram $>6$ jam yang lalu.

Dengan demikian kerena terdapat perbedaan pada variabel perilaku narsisisme, peneliti melakukan analisis lanjutan untuk melihat perbedaan rata-rata pada variable perilaku narsisisme. Berikut deskripsi perbedaan rata-rata tersebut:

Tabel 18. Perbedaan rata-rata perilaku narsisisme berdasarkan waktu terakhir kali menggunakan Instagram

\begin{tabular}{ccc}
\hline $\begin{array}{c}\text { Waktu Terakhir } \\
\text { Menggunakan } \\
\text { Instagram }\end{array}$ & $\begin{array}{c}\text { Rata- } \\
\text { rata } \\
\text { (mean) }\end{array}$ & $\begin{array}{c}\text { Jumlah } \\
\text { Subjek }\end{array}$ \\
\hline <1 Jam yang lalu & 74,01 & 105 \\
>6 Jam yang lalu & 67,10 & 20 \\
\hline
\end{tabular}

Berdasarkan data diatas dapat diketahui bahwa subjek yang terakhir kali menggunakan instagram <1 jam yang lalu memiliki nilai rata-rata narsisisme $(74,01)$ lebih besar dari pada subjek yang terakhir kali menggunakan instagram $>6$ jam yang lalu $(67,10)$.

Selanjutnya peneliti juga melakukan analisis lanjutan untuk melihat perbedaan rata-rata pada variabel citra diri. Berikut deskripsi perbedaan rata-rata tersebut:

Tabel 19. Perbedaan rata-rata citra diri berdasarkan waktu terakhir kali menggunakan Instagram

\begin{tabular}{ccc}
\hline $\begin{array}{c}\text { Waktu Terakhir } \\
\text { Menggunakan } \\
\text { Instagram }\end{array}$ & $\begin{array}{c}\text { Rata- } \\
\text { rata } \\
\text { (mean) }\end{array}$ & $\begin{array}{c}\text { Jumlah } \\
\text { Subjek }\end{array}$ \\
\hline <1 Jam yang lalu & 54,74 & 105 \\
>6 Jam yang lalu & 50,75 & 20 \\
\hline
\end{tabular}

Berdasarkan data diatas dapat diketahui bahwa subjek yang terakhir kali menggunakan instagram $<1$ jam yang lalu memiliki nilai rata-rata citra diri $(54,74)$ lebih besar dari pada subjek yang terakhir kali menggunakan instagram $>6$ jam yang lalu $(50,75)$.

Hasil uji hipotesis antara citra diri dengan perilaku narsis menunjukan nilai signifikansi sebesar $0,000 \quad(\mathrm{p}<0,05)$, sehingga hipotesis yang diajukan dalam penelitian ini diterima. Kemudian berdasarkan hasil analisis korelasi (r) antara citra diri dengan perilaku narsisisme menunjukan korelasi positif sebesar 0,772. Dengan demikian dapat dinyatakan bahwa terdapat hubungan positif yang signifikan antara citra diri dan perilaku narsisisme pada remaja putri di Kota Prabumulih. Artinya semakin positif citra diri yang dimiliki maka semakintinggi perilaku narsisisme tersebut, demikian pula sebaliknya semakin negatifcitra diri yang dimiliki maka semakin rendah perilaku narsisisme yang dimiliki.

Hal ini sesuai dengan teori yang dikemukakan oleh Pincus et al. (2009) narsisisme dapat dikonseptualisasikan sebagai kemampuan seseorang untuk mempertahankan citra diri yang relatif positif melalui berbagai proses pemahaman diri dan pengaturan diri. Selain itu berdasarkan hasil wawancara pada remaja putri di Kota Prabumulih, bahwa dengan mempertunjukan kondisi terbaik dari diri serta pandangan dan citra yang positif dapat 
membuat subjek mencapai eksistensi yang diinginkan melalui media sosial instagram, yang mana perilaku tersebut mengarahkan individu pada perilaku narsisisme.

Berdasarkan hasil analisis data, dapat dilihat bahwa remaja putri di Kota Prabumulih memiliki perilaku narsisisme yang berada pada kategori sedang dan tinggi, yaitu sebanyak 104 orang dengan persentase sebesar $68,9 \%$ berada pada kategori sedang dan sebanyak 47 orang dengan persentase sebesar $31,1 \%$ berada pada kategori tinggi. Dengan demikian dapat dikatakan bahwa mayoritas remaja putri di Kota Prabumulih memiliki perilaku narsisisme yang berada pada kategori sedang.

Hal ini dikarenakan subjek dalam penelitian merupakan subjek yang tergolong ke dalam tingkatan narsisisme yang sehat bukan patologis atau ditingkat yang ekstrim sesuai dengan kriteria subjek penelitian yang telah ditentukan sebelumnya. Kondisi sedang ini dapat diartikan bahwa sebagian besar remaja putri di Kota Prabumulih mampu menghargai dirinya secara positif dengan memahami kelebihan dan kelemahan yang dimilikinya. Hal ini diperkuat dengan pernyataan Campbell dan Miller (2011) bahwa narsisisme yang sehat dicirikan oleh diri yang terintegrasi yang mencerminkan kesadaran dan penerimaan kekuatan serta kelemahan seseorang.

Selanjutnya berdasarkan hasil analisis sebagian besar citra diri remaja putri di Kota Prabumulih juga berada pada kategori antara positif dan negatif yaitu berjumlah 104 orang dengan persentase sebesar $68,9 \%$. Kemudian sisanya sebanyak 47 orang berada pada kategori positif dengan persentase sebesar 31,1\%.

Berkaitan dengan hal tersebut Lusi (2010) mengatakan bahwa jika seseorang hidup dilingkungan negatif maka akan terbentuk citra diri yang negatif, begitupun sebaliknya jika seseorang hidup dilingkungan positif maka akan terbentuk citra diri yang positif. Dengan demikian wajar jika citra diri remaja putri di Kota Prabumulih sebagian besar berada pada kategori antara positif dan negatif, hal ini dikarenakan lingkungan pertemanan subjek baik dimedia sosial maupaun bukanmerupakan lingkungan yang cukup positif. Berdasarkan hasil wawancara, subjek mengatakan walaupun tujuan mereka menggunakan media sosial instagram untuk memeproleh eksistensi masing-masing, mereka tidak pernah saling membuli atau menjatuhkan satu sama lain baik melalui media sosial instagram maupun diluar media sosial instagram.

Namun terdapat beberapa subjek yang memliki citra diri pada kategori positif, hal ini dapat dilihat dari hasil wawancara bahwa sebagian lagi dari subjek kebanyakan mem-follow akun-akun seperti selebgram sehingga standar diri serta pandangan diri yang terbentuk cukup tinggi, yang pada akhirnya akan membentuk citra diri positif.

Kemudian peneliti melakukan analisis uji beda untuk melihat perbedaan rata-rata perilaku narsisisme berdasarkan jumlah followersinstagram. Hal ini menunjukan bahwa rata-rata perilaku narsisisme pada subjek yang memiliki jumlah followers instagram $>2000$ terbukti lebih tinggi dibandingkan dengan subjek yang memiliki jumlah followers instagram200-500. Hal ini sesuai dengan pernyataan Yaqin (2016) dalam penelitiannya bahwa salah satu faktor penyebab perilaku narsisisme adalah faktor lingkungan seperti lingkungan pergaulan dan media sosial. Seiring dengan pernyataan tersebut Widiyanti dkk (2017) dalam penelitiannya menyebutkan bahwa faktor-faktor yang mempengaruhi narsisisme salah satunya adalah lingkungan pergaulan.

Dengan demikian lingkungan pergaulan atau pertemanan subjek dalam media sosial instagram (followers) mempengaruhi besar atau tidaknya perilaku narsisisme pada subjek tersebut. Menurut Santi (2017) dalam penelitiannya menyebutkan bahwa makin banyak memiliki teman, makin meningkat narsisisme individu tersebut didunia nyata, dan hasil penelitiannya menunjukkan bahwa individu yang memiliki sedikit teman tidak menonjolkan perilaku 
narsisisme. Hal ini sesuai dengan hasil analisis uji beda yang dilakukan oleh peneliti bahwa rata-rata perilaku narsisisme pada subjek yang memiliki jumlah followers instagram 200-500 lebih rendah dibandingkan dengan subjek penelitian yang lainnya.

Namun hasil uji beda yang dilakukan oleh peneliti berdasarkan jumlah followers yang dimiliki subjek, tidak terdapat perbedaan perilaku narsisisme pada subjek yang memiliki jumlah followers 1100-1400 dan 1700-2000. Berdasarkan hasil wawancara yang dilakukan, hal ini dapat terjadi karena subjek yang memiliki jumlah followers dengan rentang antara 1100-1400 dan 1700-2000 memiliki tingkatan narsisisme yang sama yaiu sedang. Hal ini terlihat dari pernyataan antara kedua subjek yang sama-sama mengatakan bahwa mereka merasa sudah menjadi orang yang cukup eksis di instagram, walaupun belum sama eksistensinya dengan selebgram.

Selain berpengaruh terhadap perilaku narsisisme, hasil analisis menunjukan bahwa terdapat perbedaan ratarata citra diri yang dimiliki oleh remaja putri di Kota Prabumulih yang memiliki jumlah followers instagram $>2000$ terbukti lebih tinggi dibandingkan dengan subjek yang memiliki jumlah followers instagram 200-500. Hal ini seiring dengan pernyataan Devya (2015) dalam penelitiannya, bahwa lingkungan sekitar merupakan salah satu faktor yang berperan dalam pembentukan citra diri seseorang. Kemudian menurut Burns (1993: 80) citra diri dipelajari melalui pengalaman, terutama melalui interaksi sosial dengan orang-orang. Dengan demikian semakin banyak jumlah followers yang dimiliki, semakin banyak dan sering interaksi sosial terjadi melalui media sosial instagram yang mana dapat mempengaruhi pembentukan citra diri seseorang.

Kemudian berdasarkan hasil uji beda yang dilakukan oleh peneliti berdasarkan jumlah followers yang dimiliki subjek, tidak terdapat perbedaan citra diri pada subjek yang memiliki jumlah followers 1100-1400, 1700-2000 dan $>2000$. Berdasarkan hasil wawancara yang dilakukan, kedua subjek sama-sama mengatakan bahwa dengan memilki jumlah followers yang banyak maka akan semakin banyak pula yang memeberikan like pada foto-foto mereka di instagram, sehingga subjek merasa bahwa foto-foto yang mereka posting di instagram itu menarik. Dari pernyataan tersebut, dapat dilihat bahwa subjek yang memiliki jumlah followers diatas 1100 memiliki gambaran diri yang sama-sama positif, sehingga tidak terdapat perbedaan citra diri antara subjek yang memiliki jumlah followers 1100-1400 dengan 1400-17000 dan >2000. Kemudian berdasarkan pengkategorian skor total skala citra diri, subjek yang memiliki jumlah followers diatas 1100 termasuk kedalam kategori positif yaitu diatas 57 .

Selain jumlah followers instagram, terdapat faktor lain yang berpengaruh terhadap perilaku narsisisme remaja putri di Kota Prabumulih yaitu berdasarkan waktu terakhir kali menggunakan instagram. Hasil analisi uji beda yang dilakukan peneliti menunjukan bahwa subjek yang terakhir kali menggunakan instagram $<1$ jam yang lalu $(74,01)$ memiliki rata-rata perilaku narsisisme yang lebih tinggi dibandingkan subjek yang terakhir kali menggunakan instagram $>6$ jam yang lalu $(67,10)$. Hasil ini diperkuat dengan pernyataan Moon et al (2016) yang menunjukan bahwa individu yang lebih tinggi narsisismenya, cenderung memposting foto, memperbarui profil dan menghabiskan lebih banyak waktu di instagram.

(2017) Selain itu Luvy dan Rachmah menyebutkan berbagai studi menunjukan bahwa tingkat narsisisme juga berpengaruh terhadap intensi penggunaan media sosial. Individu dengan level narsisisme tinggi seringkali melakukan updates terhadap statusnya, mempromosikan diri secara berlebih dan memperoleh teman sebanyakbanyaknya. Sesuai dengan hasil analisis penelitian, subjek yang terakhir kali menggunakan instagram $>6$ jam yang lalu (kurang aktif dan intens) memiliki rata-rata perilaku narsisisme paling rendah yaitu 
67,10 .

Subjek penelitian yang terakhir kali menggunakan instagram <1 jam yang lalu dengan rata-rata sebesar 54,74 juga memiliki rata-rata citra diri yang lebih tinggi dibandingkan subjek yang terakhir kali menggunakan instagram $>6$ jam yang lalu dengan rata-rata sebesar 50,75. Hasil ini mendukung hasil penelitian yang dilakukan oleh Andarwati (2016) bahwa terdapat hubungan citra diri dengan intensitas penggunaan media sosial instagram, individu akan terus memposting atau menampilkan foto, saling bertukar komentar dan menyukai foto yang diunggah dan bersaing untuk mendapatkan followers yang banyak.

Dengan demikian semakin sering subjek menggunakan instagram, tentunya akan semakin sebentar rentang waktu terakhir kali subjek menggunakan instagram dan sebaliknya. Sesuai dengan hasil penelitian bahwa subjek yang terakhir kali menggunakan instagram $>6$ jam yang lalu memiliki rata-rata citra diri yang lebih rendah dibandingkan dengan subjek yang menggunakan instagram <1 jam yang lalu.

\section{SIMPULAN DAN SARAN}

\section{Simpulan}

Berdasarkan hasil pembahasan pada penelitian ini, dapat disimpulkan bahwa citra diri memiliki hubungan yang signifikan dengan perilaku narsisisme pada remaja putri di Kota Prabumulih, sehingga hipotesis dalam penelitian ini diterima. Kemudian berdasarkan nilai korelasi dapat disimpulkan bahwa hubungan antara citra diri dengan perilaku narsisisme remaja putri Kota Prabumulih bersifat positif.

\section{Saran}

Bagi remaja putri di Kota Prabumulih, diharapkan para remaja dapat menggunakan media sosia instagram untuk hal-hal yang lebih positif sebagai wadah untuk mengeksplore kelebihan yang ada pada diri dan lebih termotivasi untuk mengembangkan kemampuan-kemampuan pada diri, sehingga tidak sekedar memfollow akun-akun populer hanya untuk mengikuti trend masa kini. Namun menjadikan fungsi media sosial terkhususnya instagram dapat dimanfaatkan dengan lebih optimal dari sebelumnya.

Bagi peneliti selanjutnya, sebaiknya melakukan analisa dengan mempertimbangkan variabel-variabel lain yang terkait dengan fenomena dalam media sosial. Diharapkan dapat memperluas karakteristik dari subjek penelitian, seperti dalam hal jenis kelamin sehingga dapat melihat bagaimana bentuk narsisisme pada remaja laki-laki yang tidak diteliti dalam penelitian ini. Kemudian peneliti selanjutnya juga diharapkan dapat menggunakan alat ukur yang lebih baik terutama untuk mengukur variabel narsisisme itu sendiri.

\section{DAFTAR PUSTAKA}

Andarwati, I. (2016). Citra diri ditinjau dariintensitas penggunaan media jejaring sosial instagram pada siswa kelas XI SMA N 9 Yogyakarta. Skripsi. Fakultas Ilmu Pendidikan, Universitas Negeri Yogyakarta.

Apsari, F. (2012). Hubungan antara kecenderungan narsisisme dengan minat membeli kosmetik merek asing pada pria metroseksual .Talenta Psikologi, 1(2), 183-202.

Beynon, G. (2008). Mirror mirror. England: Inter-Varsity Press.

Bergman, S.M., Fearrington, M.E., Davenport, S.W., \& Bergman, J.Z. (2011). Millennials, narcissism, and social networking: what narcissists do on socialnetworking sites and why. Personality and Individual Differences, 50, 706-711. Doi: 10.1016/j.paid.2010.12.022.

Burns, R.B. (1993). Konsep diri. Jakarta: Arcan.

Campbell, W.K., \& Miller, J.D. (2011). The handbook of narcissism and narcissistic personality disorder: theoretical approaches, empirical finding and treatments. NJ: John Wiley \& Sons, Inc.

Chaplin, J.P. (2005). Kamus lengkap psikologi. Jakarta: Raja Grafindo 
Persada.

Devya. (2015). Hubungan citra diri dan perilaku konsumtif pada remaja putri yang memakai kosmetik wajah. $e$ Journal Psikologi, 3(1), 433-440.

Gunawan, W.A. (2003). Born to be a genius. Jakarta: PT. Gramedia Pustaka Utama.

Hamka. (2015). Penggunaan internet sebagai media pembelajaran pada mahasiswa IAIN Palu. Jurnal Studia Islamika, 12(1), 95-119.

Handayani, N. (2014). Hubungan antara kontrol diri dengan narsisisme pada remaja pengguna facebook. Naskah Publikasi. Fakultas Psikologi, Universitas Muhammadiyah Surakarta.

Hoft, I. (2001). Anda merasa di tolak!?. Jakarta: Gunung Mulia.

Holden, R. (2007). Success intelligence. Bandung: Mizan.

Indriani, E. (2017). Sejarah dan perkembangan instagram. Diunduh darihttp://ilmuti.org/wpcontent/uploads/2017/02/EkaIndriani-Sejarah-dan-PerkembanganInstagram-1.pdf 28 Februari 2018.

Lam, Z.K.W. (2012). Narcissism and romantic relationship: the mediating role of perception discrepancy. Discovery-SS Student E-Journal, 1(1), 1-20.

Levy, K.N. (2012). Subtypes, dimensions, levels, and mental states in narcissism and narcissistic personality disorder. Journal of Clinical Psychology: In Session, 112. DOI: $10.1002 /$ jclp. 21893.

Lusi, S.S. (2010). The real you is the real success. Jakarta: Gramedia Pustaka Utama.

Luvy, K., \& Rachmah, E.N. (2017). Relasi narsisisme dan konsep diri pada pengguna instagram. Prosiding SEMNAS, 136-142.

Manampiring, R.A. (2015). Peranan media sosial instagram dalam interaksi sosial antar siswa SMA Negeri I Manado (Studi Pada Jurusan IPA Angkatan 2012). e-Journal Acta Diurna, 4(4), 1-8.
Matthews, A. (1997). Being happy!. Jakarta: Gramedia Pustaka Utama.

Nevid, J.S., Rathus, S.A., \& Greene, B. (2005). Psikologi abnormal (5 ${ }^{\text {th }}$ ed.). Jakarta: Erlangga.

Pincus, A.L., Ansell, E.B., Pimentel, C.A., Cain, N.M., Wright, A.G.C., \& Levy, K.N. (2009). Initial construction and validation of the pathological narcissism inventory. Psychological Assessment, 21(3), 365-379. DOI: $10.1037 / \mathrm{a} 0016530$

Santi, N.N. (2017). Dampak kecenderungan narsiscisme terhadap self esteem pada pengguna facebook mahasiswa PGSD UNP. Jurnal Dimensi Pendidikan dan Pembelajaran, 5(1), 25-30.

Santrock, J.W. (2002). Life-Span development: Perkembangan masa hidup $\left(13^{\text {th }}\right.$ ed.). Jakarta: Erlangga.

Sarwono, S.W. (2016). Psikologi remaja. Jakarta: Rajawali Pers.

Seamands, D.A. (1981). Healing for damaged emotions. Canada: David C Cook.

Suhartanti, L. (2016). Pengaruh kontrol diri terhadap narcissistic personality disorder pada pengguna instagram di SMAN 1 Seyegan. e-Journal Bimbingan dan Konseling, 8(5), 184195.

Vania, R. (2016). Mayoritas pengguna aktif instagram di Indonesia. Diunduh dari http://www.tribunnews.com/techno/2 016/01/15/mayoritas-pengguna-aktifinstagram-di-indonesia-adalah-anakmuda.

VandenBos, G.R. (2007). APA Dictionary of psychology ( $2^{\text {nd }}$ Edition). DC: American Psychological Assocation.

Widiartanto, Y.H. (2017). Instagram dinilai buruk untuk kesehatan jiwa remaja. Diunduh dari http://tekno.kompas.com/read/2017/0 5/21/09345137/instagram.dinilai.bur uk.untuk.kesehatan.jiwa.remaja 27 Februari 2018.

Widiyanti, W., Solehuddin, M., \& Saomah, A. (2017). Profil perilaku narsisisme remaja serta implikasinya bagi bimbingan dan konseling. Indonesian 
Journal of Educational Counseling, l(1), 15-26.

Yaqin, B.I.A. (2016). Fenomena narsisisme dikalangan siswi SMK ma'arif tunjungan blora dan solusi penangannya dengan bimbingan dan konseling. Skripsi. Fakultas Dakwah dan Komunikasi, UIN Semarang 